\title{
Success and resilience factors of rural enterprises in Mexico: RENDRUS case
}

\author{
Cordero-Cortés, Patricia ${ }^{\circledR}$; Márquez-Berber, Sergio R. ${ }^{(1) *}$ \\ Universidad Autónoma Chapingo. Chapingo, Texcoco, Estado de México, México. C. P. 56230. \\ * Correspondence: drsergiomarquezb@gmail.com
}

Citation: Cordero-Cortés, P., \& Márquez-Berber, S. R. (2021). Success and resilience factors of rural enterprises in Mexico: RENDRUS case. Agro Productividad. https://doi.org/ 10.32854/agrop.v14i12.2032

Editor in Chief: Dr. Jorge Cadena Iñiguez

Received: May 11, 2021.

Accepted: December 14, 2021.

Published on-line: December 30, 2021.

Agro Productividad, 14(12). December. 2021. pp: 111-117.

This work is licensed under a Creative Commons Attribution-NonCommercial 4.0 International license.

\begin{abstract}
Objective: To identify the success and resilience factors of rural enterprises in Mexico in order to contribute to the theoretical and empirical differentiation of these concepts.

Design/Methodology/Approach: We used the National Network for Sustainable Rural Development Companies as a case study to formulate key questions to identify their success and business resilience factors.

Results: Permanent job creation turned out to be the main success factor, and timely delivery of the product was the main resilience factor.

Study Limitations/Implications: Recognizing the difference between success and resilience factors can help rural enterprises, their leaders, and decision-makers in the rural sector to understand and adjust their operating strategies based on their objectives.

Findings/Conclusions: A success factor is a way to stand out among similar rural enterprises, while a business resilience factor serves to face adversity and continue over time.
\end{abstract}

Keywords: success, failure, agribusiness.

\section{INTRODUCTION}

Enterprises are a fundamental pillar of the economy as they are centers for the generation of economic resources and value (Pavón, 2010). In 2018 there were 4,057,719 enterprises in Mexico, out of which $97.1 \%$ were microenterprises, $2.7 \%$ were small and medium-sized, and $0.3 \%$ were large (INEGI, 2018); the rural enterprises of this study are found in the first category. According to Arvelo (2004), the rural enterprise is an organization located in the rural sector whose purpose is to generate profits from the use of the factors and capitals of its territory.

Rural enterprises are not exempt from recurring problems that place them in a situation of low survival. In this regard, Pavón (2010) indicates that in 2008, only 17.5\% of Mexican enterprises survived and the other $80 \%$ of these enterprises closed down definitively before reaching their first year of operation.

The word "success" of an enterprise is a very broad and subjective concept; Luk (1996) mentions that a company can be successful when the owner or manager has obtained a surplus in profits. The literature identifies success factors with different approaches, including natural leadership, responsibility and honesty of the leaders, permanent training, adequate financing, and elimination of intermediaries (Valtierra et al., 2008); the business plan, management, operational procedures, and conflict resolution (Avendano-Alcaraz et al., 2009); available technology, the offer of more than one product, and high market integration

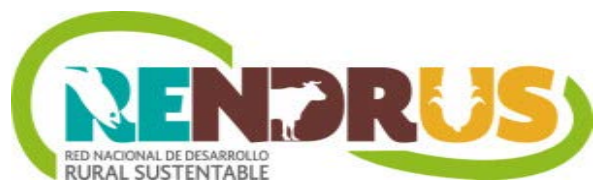


(Remilien et al., 2018); the degree of schooling, the number of years in productive activity, trust in government institutions and relational capital (Jaramillo et al., 2013).

Valtierra et al. (2008) indicate that the factor that leads to success in more than $75 \%$ of rural economic organizations is for the organizational process to be truly assumed by its members. The success factors of an enterprise are not necessarily the same as the resilience factors.

Resilience is an ability to surface from adversity, adapt, recover and access a meaningful and productive existence (Kotliarenco et al., 1997). In turn, Meneghel, Salanova and Martínez (2013) point out that business resilience is composed of factors originating from critical or adverse situations, resulting from the weaknesses and threats faced by the enterprises.

Theory states that any significant disruption has consequences on the enterprise's performance, whether in sales, production level, customer service or other (Sheffi \& Rice, 2005). It also states that the disruptive situation faced by the company has eight phases (Sheffi \& Rice, 2005); in this regard, Sanchis and Poler (2011) explain that it would be valuable to be able to identify the factors of business resilience even before the preparation phase of the enterprise. This study addresses the need to identify the factors that make the company resilient.

The concept of resilience used in this study refers to the capacity of rural enterprises to face adversities, crises and uncertainties, through their risk and protective factors, in a given period, so that changes and ruptures can be generated to prevail over time (Cordero et al., 2014).

The objective of this study was to analyze the factors of success and business resilience of rural enterprises in Mexico, through their identification, with the purpose of contributing to broaden these concepts and to understand the actions that contribute to the survival of the enterprises. The hypothesis underpinning the present study was that the success and the resilience of rural enterprises are connected because there may be factors that contribute to the success of rural enterprises and coincide with factors that contribute to business resilience. However, they are different concepts that should not be expressed as synonyms.

\section{MATERIALS AND METHODS}

The objective of the study were the 1,278 rural enterprises of the National Network for Sustainable Rural Development (Red Nacional de Desarrollo Rural Sustentable, RENDRUS) during the period 2004-2010, located throughout the country. The base was generated from information of the enterprises at www.rendrus.gob.mx that was available until 2015, where the leaders of the rural enterprises (owners or legal representatives) expressed the success factors of the enterprises they represent. The research was qualitative. The critical success factors methodology proposed by Romero et al. (2009) was used, which is characterized by the collection of information through questions. The success of an enterprise was identified through the question: What has made your company different to generate more profits or to differentiate its product or service? The question was formulated based on Luk's (1996) definition of success. The resilience was identified through the question: What action did 
the company have to implement to face certain adversity that allowed it to continue through time and be in a better situation? The question was formulated in this way to identify the resilience factors of the rural enterprise (Sanchis \& Poler, 2011). Finally, the proportion of the presence of business success and resilience factors was calculated for the total number of enterprises.

\section{RESULTS AND DISGUSSION}

The enterprises studied were classified into three types according to their characteristics.

Data analysis consisted of a list of 178 success and resilience factors of the companies under study, which were classified into 116 success factors and 99 resilience factors. The success factors of the companies studied are shown in Table 2. The percentages indicated in the tables represent the proportional share of each factor in the companies studied, showing the top ten.

A success factor is determined by the benefits it generates. The main factor found in rural enterprises that participate in the RENDRUS is permanent self-employment. Remilien et al. (2018) point out as one of the main factors for the creation and permanence of microenterprises that people have no other work option, and these are known as entrepreneurs out of necessity.

In the type of organization of the rural enterprise, informal groups stand out, which are established by friends, family, and temporary workers. According to Hernández (2007), the family system plays a major role in the performance of the enterprise, as a result of the permanent search to guarantee the family's well-being and economic stability.

Another success factor identified is having a high production volume, resulting from high yields or greater product generation. In this regard, Belausteguigoitia (2003) suggests that the focus on productive aspects is a common characteristic of family businesses, as they tend to be oriented towards production and sales.

Profit is considered as an indicator that influences the success of rural enterprises, the representatives of the enterprises express that the economic activity must generate profits for the family or for the partners. However, this result is opposite to what was analyzed

Table 1. Classification and characteristics of the rural enterprises studied.

\begin{tabular}{|c|c|c|}
\hline Rural Microenterprise A & Rural Microenterprise B & Rural Microenterprise C \\
\hline $\begin{array}{l}\text { Informal and family microenterprise, more } \\
\text { than ten years of existence, less than } 5 \\
\text { members. The business has basic services. } \\
\text { Few tools and without information and } \\
\text { communication technologies (ICTs). It has } \\
\text { used financing. Does not receive training in } \\
\text { a continuous manner. There is trust between } \\
\text { members of the enterprise and the suppliers. } \\
\text { Strengths: discipline and honesty. Lack of } \\
\text { economic resources to invest in labor capital. } \\
\text { They reinvest } 60 \% \text { of income or less. }\end{array}$ & $\begin{array}{l}\text { Informal and family microenterprise, with } \\
\text { more than five years of existence. Between } \\
1 \text { and } 3 \text { employees. Direct sale to the local } \\
\text { consumer. Does not have the necessary } \\
\text { infrastructure to work, has basic services, } \\
\text { sufficient tools and equipment. Low } \\
\text { technological level since there are no ICTs. } \\
\text { Never has had access to financing or training. } \\
\text { Strengths: good customer care and product } \\
\text { quality. Lacks economic resources to invest in } \\
\text { labor capital. }\end{array}$ & $\begin{array}{l}\text { Family microenterprise, of } 6 \text { members or } \\
\text { more. Direct sale to the local consumer. It } \\
\text { has basic services, without access to ICTs, } \\
\text { financial resources or training. The members } \\
\text { of the family do not receive a salary for } \\
\text { their work, } 70 \% \text { of their income is reinvested } \\
\text { in the activity. It is a disciplined group in } \\
\text { work. Lacks economic resources for labor } \\
\text { capital. Good quality product. It does not } \\
\text { have product variety, price according to } \\
\text { production costs. Without new market } \\
\text { options. }\end{array}$ \\
\hline
\end{tabular}

Source: Prepared by the authors with information from www.rendrus.gob.mx 
Table 2.

\begin{tabular}{l|l|c}
\multicolumn{1}{c|}{ Success Factor } & \multicolumn{1}{c}{ Definition } & Percentage \\
\hline $\begin{array}{l}\text { Permanente self- } \\
\text { employment }\end{array}$ & $\begin{array}{l}\text { Giving work to someone to conduct an activity permanently, including the owner of the } \\
\text { Enterprise. }\end{array}$ & $\begin{array}{l}\text { Social system designed to achieve goals and objectives through human resources or talent } \\
\text { management. }\end{array}$ \\
\hline $\begin{array}{l}\text { Type of organization }{ }^{\&} \\
\text { High production }^{*}\end{array}$ & $\begin{array}{l}\text { Having high yields in its production, whether agriculture and livestock, or agriculture and } \\
\text { industry. }\end{array}$ & 8.6 \\
\hline Temporal employment $^{\&}$ & Employing someone in the performance of a productive activity seasonally. & 6.6 \\
\hline Profit $^{\$}$ & It is the net benefit obtained by the capital invested in the enterprise. & 6.2 \\
\hline Benefit generated $^{\$}$ & It is the economic and social benefit obtained by the establishment of the enterprise. & 3.4 \\
\hline Experiencia $^{*}$ & Form of knowledge or ability derived from observation, housing or from practice. & 3.2 \\
\hline Capacity installed $^{*}$ & $\begin{array}{l}\text { Generating a maximum production volume during a specific period, considering the local } \\
\text { resources. }\end{array}$ & 3.1 \\
\hline $\begin{array}{l}\text { Quality } \\
*\end{array}$ & Set of properties inherent to a product or service to satisfy implicit or explicit needs. & 3.1 \\
\hline $\begin{array}{l}\text { Acceptance of the } \\
\text { product }\end{array}$ & Acceptance of the product or service and amount that it is willing to acquire. & 3.1 \\
\hline
\end{tabular}

Note: Factor classification: ${ }^{\&}$ Organizational, ${ }^{\$}$ Economic, ${ }^{*}$ Productive.

Source: Own elaboration with information from www.rendrus.gob.mx

by Remilien et al. (2018), where they compare rural micro-entrepreneurs against normal entrepreneurs, and found that the former aim at survival and the latter aim at profit. The main resilience factors identified are shown in Table 3.

The elements indicated in Table 3 are considered as resilient because they are the skills and capacities that the enterprise has and that allow it to remain in the long term meeting its economic, social and environmental objectives.

Table 3. Main resilience factors of rural enterprises (2004-2010).

\begin{tabular}{|c|c|c|}
\hline Resilience Factor & Definition & Percentage \\
\hline Timely delivery \& & Fulfilling the time agreed with the delivery of products and services. & 16.8 \\
\hline Effective commercialization \& & $\begin{array}{l}\text { Way in which they trade the product: individual (even going to the address), collective (in } \\
\text { association with another enterprise), or both. }\end{array}$ & 12.1 \\
\hline Productive capacity* & $\begin{array}{l}\text { It is the maximum level of activity that can be reached with a productive structure } \\
\text { within the enterprise. }\end{array}$ & 9.6 \\
\hline Broad client portfolio $^{\&}$ & Having a broad number of clients. & 6.6 \\
\hline Professional management ${ }^{\&}$ & $\begin{array}{l}\text { The person that leads the enterprise has an adequate professional profile to develop this } \\
\text { activity. }\end{array}$ & 5.5 \\
\hline Biotechnology* & Application of new technologies in biological processes or agricultural production. & 3.4 \\
\hline Group discipline ${ }^{\&}$ & $\begin{array}{l}\text { Each of the members of the enterprise respects a schedule, hierarchical levels, and } \\
\text { activities. }\end{array}$ & 3.3 \\
\hline Exports $^{\$}$ & $\begin{array}{l}\text { Selling the products generated to other countries. The enterprises that have a market } \\
\text { outside, which are considered a competitive advantage. }\end{array}$ & 3.3 \\
\hline Distribution $^{\&}$ & The way in which products are taken from the production unit to the final consumer. & 2.7 \\
\hline Support received $\$$ & Sources of help for something to happen. & 2.6 \\
\hline
\end{tabular}

Note: Factor classification: \&Organizational, \$Economic, *Productive.

Source: Own elaboration with information from www.rendrus.gob.mx 
In the case of the RENDRUS enterprises, timely delivery was identified as the main resilience factor. This finding coincides with that analyzed by Sanchis \& Poler (2011) who report how timely delivery impacted an increase in market share from $27 \%$ to $30 \%$. Therefore, it is advisable to adopt strategies that take into account production parameters, timeliness and delivery of the product or service to meet customer expectations and face the competition.

Partnering with other companies to market the product allows to decerase marketing costs and cover larger-scale orders. In this regard, Rubio and Aragón (2008) state that one of the sources of competitive success is commercial resources such as access to markets and distribution channels, so companies must respond quickly to trends.

Businesses have had to expand their production capacity to meet unsatisfied demand and abide by their customers. Production capacity is the result of the decision to increase market share; it is a productive and technological decision (Tapia, 2012). The resilience factor "productive capacity" is related to the success factors of "high production" and "own installed capacity"; these factors generate strength in the company to respond to such demand.

Professional management refers to the fact that it is desirable for the administration of the company to be entrusted to a professional person, because of his or her ability to make appropriate decisions. However, professionalization is a process of gradual transformation that implies a change of mentality in each of the members of the enterprise (Belausteguigoitia, 2003).

Biotechnology is defined as "any technological application that uses biological systems and living organisms or their derivatives to create or modify products or processes for specific uses" (SCDB, 2018). The use of agricultural biotechnology is a resilience factor because it strengthens rural enterprises, since it has an impact on the quality and level of production; in addition, in order to use it, it is necessary to receive training, thus strengthening the enterprise with technological knowledge.

Finally, to compare a success factor and a business resilience factor, the following definitions are set out in Table 4.

As can be seen in Tables 2 and 3, the hypothesis that the success factors were not the same as the resilience factors for the rural enterprises studied is proven; however, a similarity was found between high production, own installed capacity, and productive capacity. In addition, there are resilience factors that contribute to the success of the enterprises, as pointed out by Rubio and Aragón (2008) referring to marketing, and other factors that

Table 4. Success factor and resilience factor of rural enterprises.

\section{Success Factor}

Internal and external factor that responds to a predefined standard by a development model that influences the enterprise positively, placing it as reference for other enterprises, since it presents singular characteristics that allow it to be different from others (SAGARPA, 1996).

\section{Resilience Factor}

Element that promotes the capacity to face critical situations, through the recognition of risk and protection factors of the enterprise, which allows absorbing changes, ruptures and prevailing in time (own definition).

Source: Prepared by the authors. 
were considered by Gibb and Ritchie (1982) as necessary to have a successful start were motivation and determination. Finally, we find that Morales-Jiménez et al. (2015), in their study with rural microenterprises, found that schooling is a success factor for enterprises, which is related to professional management.

The results serve as a reference to generate strategies that help the business sector to make decisions that help to prepare the company to face disruptive events or critical situations, thus achieving resilience. It was identified that the greatest number of critical situations occurred in economic, productive and organizational aspects, so it is in these areas where more resilience factors have been developed, as indicated by López et al. (2011). It is important to note that an enterprise can be resilient and also successful, which is the best-case scenario. However, although business success and resilience are related attributes, a company does not always have both characteristics.

\section{CONGLUSIONS}

There is an important difference between a business success factor and a business resilience factor, and it lies mainly in the fact that success is a way of standing out among similar companies, while a business resilience factor serves to face adversities and continue over time.

The success factors are mainly economic and productive, as opposed to the resilience factors, which are mostly organizational. With these results, the hypothesis set out was confirmed. Identifying both factors can help rural enterprises to understand and adjust their strategies for permanence despite adversities. Permanent self-employment, type of organization and high production were the main success factors of the enterprises studied, while customer service, effective marketing and productive capacity were the main resilience factors.

Some open lines of research are to verify whether it is possible for an enterprise to be successful but not resilient and vice versa; furthermore, with the factors identified, it is possible to propose a scale for measuring resilience in rural enterprises.

\section{REFERENCES}

Arvelo, M. 2004. Empresas rurales ¿Eslabón perdido? Series Lideres. 8th edición. Venezuela: IICA.

Avendano-Alcaraz, J., Kelly, L., Trevinyo-Rodríguez, R., Gómez, S. (2009). A family-based competitive advantage: Handling key success family factors in Mexican family businesses. Cuadernos de Administración 22(39), 191-212.

Belausteguigoitia, R. I. (2003). Empresas familiares. McGrawHill. 1ra Edición. México.

Cordero, C. P., Núñez J., Hernández O., Arana O. (2014).Factores resilientes en micro y pequeñas empresas rurales. Agricultura, Sociedad y Desarrollo 11(4), 481-498.

Gibb, A., Ritchie J. (1982). Understanding the process of starting small business. European Small Business Journal $1(1), 26-47$.

Hernández, F. L. (2007). Competencias esenciales y PyMEs familiares: Un modelo para el éxito empresarial. Revista de Ciencias Sociales 13(2), 249-263. Doi: 10.31876/rcs.v13i2.25362

INEGI. Instituto Nacional de Estadística y Geografía. (2018). Encuesta Nacional sobre Productividad y Competitividad de las Micro, Pequeñas y Medianas Empresas (ENAPROCE 2018). Disponible en: https://www.inegi.org.mx/programas/enaproce/2018/\#Tabulados

Jaramillo Villanueva, J. L., Morales Jiménez, J., Escobedo Garrido, J. S., Ramos Castro, J. G. (2013). Factores que influyen para el emprendimiento de microempresas agropecuarias en el Valle de Puebla, México. Revista Mexicana de Ciencias Agrícolas 5, 925-937. 
Kotliarenco, M., Cáceres, I., Fontecilla, M. (1997). Estado de arte en resiliencia. Organización Mundial de la Salud. Santiago, Chile. Disponible en: http://www.ugr.es/ javera/pdf/2-3-resiliencia\%20libro.pdf

López, E., Araiza Z., García, A., Tobías, Ll. (2011). Estrategias de dirección y tecnologías de información en pequeñas y medianas empresas de Coahuila. Revista Internacional Administración y Finanzas 4(1), 19-30.

Luk, S.T.K. (1996). Success in Hong Kong: Factors self-reported by successful small business owners. Journal of Small Business Management 34(3). 68-74.

Meneghel, I., Salanova, M., Martínez, I. M. (2013) El camino de la Resiliencia Organizacional: una revisión teórica. Aloma 31(2), 13-24.

Morales-Jiménez, J., Bustamante-González, Á., Vargas-López, S., Pérez-Ramírez, N., Sereno-Pareja, O. (2015). Factores de éxito emprendedor en dos municipios de la montaña de Guerrero, México. Revista Nova Scientia 7(15), 416-435.

Tapia, G. (2012). Las empresas resilientes y la relación con el valor organizacional. Pymes textiles. Tesis Doctoral 001501/1236. Universidad de Buenos Aires. Biblioteca Digital de la Facultad de Ciencias Económicas. Buenos Aires, 302p.

Pavón, L. (2010). Financiamiento a las microempresas y PyMEs en México (2000-2009). CEPAL. Serie Financiamiento del Desarrollo No. 226. 69p.

Remilien, E., Sánchez-Hernández, M., Hernández-Salgado, H., Servin-Juárez, R., Carranza-Cerda, I. (2018). Creation Profiles of Microenterprises in Rural Zones: the Case of Santa Bárbara Almoloya, Cholula, Puebla. Agricultura, Sociedad y Desarrollo 15(1), 29-45.

Romero, L. R., Noriega, M. S. A., Escobar, T. G., Ávila, D. V. (2009). Factores críticos de éxito: una estrategia de competitividad. CULCyT-Planeación Estratégica 31(6), 5-14.

Rubio, B. A., Aragón, S. A. (2008). Recursos estratégicos en la pymes. Revista Europea de Direccion y Economia de La Empresa 77(1), 103-126.

SAGARPA. (1996). Red Nacional de Desarrollo Rural Sustentable (RENDRUS). México. Disponible en: http:// www.sagarpa.gob.mx/desarrolloRural.aspx

Sanchis, R., Poler, R. (2011). Medición de la Resiliencia Empresarial ante Eventos Disruptivos. XV Congreso de Ingeniería de Organización. 104-113. Disponible en:http://adingor.es/congresos/web/uploads/cio/ cio2011/administracion_de_empresas/104-113.pdf

Sheffi Y., Rice Jr., J.B. (2005). A Supply Chain View of the Resilient Enterprise. MIT Sloan Management Review 47(1), 41-48.

Valtierra, E., Quispe, A., León, A., Figueroa, O., Jiménez, L. (2008). Organizaciones económicas exitosas del medio rural en México. México. Colegio de Posgraduados. 